\title{
REPRESENTASI PROFESIONALITAS WARTAWAN PADA FILM KILL THE MESSENGER (ANALISIS SEMIOTIKA JOHN FISKE)
}

\section{REPRESENTATION OF JOURNALISTS PROFESSIONALISM IN KILL THE MESSENGER MOVIE (JOHN FISKE'S SEMIOTIC ANALYSIS)}

\author{
Richard Jefferson ${ }^{1}$, Hermawan Pancasiwi ${ }^{2}$, Abraham Wahyu Nugroho ${ }^{3}$ \\ 1,2,3 Universitas Katolik Soegijapranata \\ email: 3abraham@unika.ac.id
}

\begin{abstract}
Movies could be used in the field of education, because it gets people's attention and conveys messages in a unique way. The film Kill The Messenger is a movie based on a true story and has a message related to the professionalism of journalist. The purpose of this research is to find out what professionalism a journalist applies to in carrying out his duties and obligations as a professional journalist in the level of reality, representation and ideology in the movie Kill The Messenger. This research used descriptive qualitative method with John Fiske's semiotic analysis with the code of television theory, where there are three stages in analyzing through the code of television theory: reality level, representation level and ideological level. From this research, researchers found signs of professionalism in the movie "Kill The Messenger".
\end{abstract}

Keywords: Professionalism, John Fiske's semiotics, movie Kill The Messenger

\begin{abstract}
Abstrak
Film dapat dimanfaatkan di dalam dunia pendidikan. Hal ini didasari karena film dapat menarik perhatian orang dan menyampaikan pesan secara unik. Film Kill The Messenger merupakan salah satu film yang diangkat dari kisah nyata dan memiliki pesan berkaitan dengan profesionalitas wartawan. Tujuan penelitian ini adalah untuk mengetahui profesionalitas apa saja yang diterapkan oleh seorang wartawan dalam melaksanakan tugas dan kewajibannya sebagai wartawan profesional dalam tingkat realitas, representasi dan ideologi pada film Kill The Messenger. Penelitian ini menggunkan metode kualitatif deskriptif dengan analisis semiotika John Fiske melalui teori The Code of Television. Analisis meliputi level realitas, level representasi dan level ideologi. Dari penelitian ini, peneliti menemukan tanda-tanda profesionalitas dalam Film "Kill The Messenger", yang meliputi representasi berita yang faktual dan jelas sumbernya, memiliki rasa terpanggil dan melayani masyarakat, memiliki rasa otonomi dalam membuat keputusan, bertanggung jawab dan transparan terhadap hasil tulisannya, profesional mengatur dirinya sendiri, dan bersifat independen.
\end{abstract}

Kata Kunci: Profesionalitas, semiotika John Fiske, film Kill The Messenger

\section{PENDAHULUAN}

Berdasarkan fungsi film sebagai media hiburan maupun media edukasi, film berkembang menjadi beragam kategori. Namun, pada dasarnya film memiliki empat kategori besar, yakni film kartun, film cerita, film berita, film jenis lain dan film dokumenter. Jenis film yang beragam tidak melepaskan film dari unsur pesan atau makna yang ingin disampaikan 
kepada penontonnya. McQuail dalam artikel yang berjudul Penerimaan Penonton Terhadap Praktik Eksorsis Dalam Film Conjuring (Oktavianus, 2015), mengatakan pesan yang terkandung dalam film timbul dari keinginan untuk merefleksikan kondisi masyarakat dan bahkan mungkin juga bersumber dari keinginan untuk memanipulasi.

Film dapat dimanfaatkan dalam pendidikan hal ini didasari oleh kemampuan film dalam menarik perhatian orang dan menyampaikan pesan secara unik. Secara mendalam film menjadi alat penyampaian sebuah pesan bagi pemirsanya dan juga sutradara. Pada umumnya film mengangkat sebuah tema atau fenomena yang terjadi di tengah masyarakat (Oktavianus, 2015). Film mampu memberikan pengaruh yang sangat besar pada penonton bahkan memiliki peluang untuk mempengaruhi dalam waktu yang cukup lama. Pengaruh terbesar yang dapat ditimbulkan sebuah film adalah imitasi atau peniruan. Pengaruh ini timbul akibat anggapan bahwa apa yang terlihat dalam sebuah film wajar atau layak untuk dilakukan setiap orang, seperti contoh menirukan gaya rambut (Wahyuningsih, 2019).

Salah satu film yang menarik untuk dibahas dalam konteks jurnalisme adalah Kill The Messenger. Film ini bercerita tentang sosok Gary Webb sebagai wartawan profesional, berjuang mengungkap kasus transaksi narkoba yang dilakukan oleh Central Intelligence Agency (CIA) untuk mendanai perang dingin di Nicaragua melalui tulisannya yang berjudul "Dark Alliance". Setelah mencari bukti yang cukup berkaitan dengan kasus ini, Gary Webb berhasil menerbitkan tulisannya di San Jose Mercury News. Namun tidak ada yang menyangka tulisan Gary Webb menimbulkan dampak yang besar bagi masyarakat maupun Central Intelligence Agency (CIA) sehingga San Jose Mercury News mendapatkan tekanan dari pihak luar. Pada akhirnya San Jose Mercury News menjadi pihak yang turut menentang berita yang ditulis Gary Webb, serta menganggap bahwa berita tersebut hanyalah khayalan Gary semata.

Film ini ingin menyampaikan sebuah pesan berkaitan dengan kinerja profesional wartawan sangat penting meskipun mendapat berbagai tekanan dari pihak yang merasa mendapat ancaman dari hasil berita yang telah dibuat. Pada dasarnya wartawan adalah suatu profesi yang penuh tanggung jawab dan memiliki risiko yang cukup besar. Profesi semacam ini diperlukan manusia-manusia yang memiliki idealisme dan ketangguhan hati yang kuat untuk menghadapi berbagai kendala, hambatan dan tantangan dalam menjalankan profesinya (Rustam, 2016).

Berdasarkan fungsi film yang memiliki kekuatan dalam menyampaikan pesan terhadap penontonnya. Serta pentingnya perilaku profesional sebagai seorang wartawan membuat penulis tertarik untuk meneliti Film Kill The Messenger. Hal ini dikarenakan di dalam Film Kill The Messenger terdapat adegan yang berkaian erat dengan kerja wartawan profesional. Film ini diangkat berdasarkan kisah nyata Gary Webb seorang wartawan San Jose Mercury News yang mengeluarkan tulisan berjudul Dark Alliance: The CIA, the Contras, and the Crack Cocaine Explosion. Dark Alliance untuk membuktikan bahwa adanya peran Central Intelligence Agency (CIA) dalam transaksi kokain untuk mendanai perang dingin di Nicaragua. Film Kill The Messenger seakan membuka mata publik akan kinerja profesional yang dilakukan oleh wartawan, bahkan film ini membuka proses pengolahan informasi yang dilakukan oleh media yang memiliki peluang besar terjadinya pemelintiran informasi, serta perilaku profesional wartawan. Berdasar storyline yang berkaitan erat dengan profesionalitas wartawan membuat peneliti tertarik menggunakan film ini sebagai obyek penelitian menggunakan analisis Semiotika John Fiske. 
Analisis Semiotika John Fiske memiliki sudut pandang berbeda dan sangat cocok digunakan untuk menganalisa makna dalam film. Hal ini dikarenakan dalam Semiotika John Fiske memiliki konsep "The Codes of Television". Pada konsep ini, John Fiske mengartikan televevisi adalah sebuah provokator dan alat peredaran makna, sehingga konsep ini akan membantu memaknai sebuah tanda dalam sajian visual agar mendapatkan pemaknaan yang unik (Fiske, 1987). Analisis Semiotika John Fiske menggunakan tiga level yakni level realitas, level representasi dan level ideologi. Ketiga level ini memiliki peran yang berbeda dalam proses pemaknaan tanda dalam sajian visual film. Berdasar latar belakang diatas, peneliti tertarik untuk meneliti Film Kill the Messenger menggunakan analisis Semiotika John Fiske. Tujuan penelitian ini adalah untuk memahami bagaimana representasi profesionalitas wartawan dalam Film Kill The Messenger dalam tingkat realitas, representasi dan ideologi pada film Kill The Messenger.

\section{Semiotika John Fiske}

John Fiske dalam bukunya Reading Television mengatakan bahwa semiotika secara sederhana didefinisikan sebagai sebuah ilmu tanda, yang akan menghasilkan sebuah makna berdasarkan bagaimana kita mengartikannya. Pusat perhatian pada semiotika dapat dinyatakan secara sederhana hanya ada dua yakni hubungan antara sebuah tanda dan sebuah makna (Fiske dan Hartley, 2004). The Codes of Television merupakan teori yang dikemukakan oleh John Fiske. Kode ini digunakan untuk meneliti makna di dalam konten pertelevisian. Menurut John Fiske dalam bukunya Television Culture, untuk memahami sebuah kode yang terdapat d idalam televisi terlebih utama kita harus menganggap bahwa televisi adalah sebuah agen budaya yang mempunyai wadah untuk memprovokasi dan menjadi wadah peredaran makna. Kode dianggap sebagai sistem tanda yang diatur oleh peraturan, aturan dan konvensinya dibagikan di antara anggota dari suatu budaya, dan yang digunakan untuk menghasilkan dan mengedarkan makna di dalam budaya itu. Kode dapat juga diartikan sebagai hubungan antara produsen, teks, khalayak dan merupakan agen intertekstualitas dimana teks saling terkait dalam hubungan makna yang menghubungkan dunia kita. Untuk mempermudah dalam mengartikan sebuah kode, John Fiske membagi menjadi tiga level yaitu level realitas, level representasi, dan level ideologi.

Level realitas merupakan sebuah kode yang berdasar pada kode sosial. Level Realitas diambil berdasarkan kejadian murni yang terjadi didalam tayangan visual. Poin yang mencakup level realitas seperti, penampilan (appearance), pakaian (dress), tata rias wajah (make-up), lingkungan perilaku (environment), cara berbicara (speech), gerakan (gesture), ekspresi (expression).

Level representasi diartikan sebagai sebuah kode teknis yang meliputi kamera (camera), pencahayaan (lighting), editing, musik (music), suara (sound). Poin pada kode teknis akan mentransmisikan representasi kode konvensional yang membentuk representasi dari, naratif (narrative), konflik (conflict), karakter (character), aksi (action), percakapan (dialogue), keadaan (setting) dan pemilihan pemain (casting). Kode tingkat ke dua ini menjadi penghubung tingkat selanjutnya yakni kode tingkat ke tiga, kode ini menjadi sebuah jembatan antara pesan yang ingin disampaikan dengan budaya yang terjadi disekitar masyarakat. Kode representasi konvensional yang terdiri dari naratif (narrative), konflik (conflict), karakter (character), aksi 
(action), percakapan (dialogue), keadaan (setting) dan pemilihan pemain (casting). Kode representasi konvensional merupakan hasil dari tranmisi kode teknis.

Level ideologi menunjukkan bagaimana kode-kode representasi di hubungkan pada koherensi sosial seperti kelas sosial ataupun kepercayaan dominan masyarakat yang termasuk didalamnya adalah individualisme (individualism), patiarki (patriarchy), ras (race), kelas (class), materialisme (materialism), kapitalisme (capitalism).

\section{Ciri Profesionalitas}

Berdasarkan dokumen dari Society Of Professional Journalist dan Peraturan Dewan Pers No. 6/ Peraturan-DP/V/2008 pasal 2, berikut adalah rangkuman yang menjadi ciri profesionalitas:

1. Menghasilkan berita yang faktual dan jelas sumbernya

2. Memiliki Rasa terpanggil dan Melayani Masyarakat

3. Menghormati hak privasi

4. Memiliki rasa otonomi dalam membuat keputusan, untuk kepentingan peliputan berita investigasi demi kepentingan publik.

5. Bertanggung jawab dan transparan terhadap hasil tulisannya.

6. Profesional mengatur dirinya sendiri

7. Bersifat independen

Wartawan harus bersikap independen. Independensi wartawan dikaitkan dengan sikap menghindari konflik kepentingan, menghindari kegiatan yang dapat membahayakan integritas atau kerusakan kredibilitas, serta menghindari suap dalam bentuk apapun. Wartawan harus menolak berbagai tawaran yang dapat mempengaruhi isi berita dan waspada terhadap orang yang menawarkan bantuan dalam proses pengumpulan informasi.

\section{METODOLOGI PENELITIAN}

Penelitian ini mengarah kepada analisis deskriptif dengan menggunakan metode penelitian kualitatif. Jenis penelitian yang akan digunakan penulis adalah jenis penelitian model analisis semiotika John Fiske. John Fiske dalam bukunya Introduction to Communication Studies mengasumsikan bahwa semua komunikasi melibatkan tanda (signs) dan kode (code) (Fiske, 1990).

Pada bagian unit analisis, peneliti akan memaparkan scene yang memiliki keterkaitan terhadap profesionalitas jurnalis, dimana scene ini nantinya akan digunakan ditahap analisis. Scene yang tidak memiliki kaintan dengan profesionalitas wartawan tidak dimasukkan peneliti kedalam unit analisis. Beberapa scene yang memiliki kaitan dengan profesionalitas wartawan yang digunakan dalam penelitian scene 15, 16, 22, 31 dan 34, 35, 38, 42, 42, 53, 62, 74, 98, 105, 143, 148, dan 150.

Pada tahap analisis data, penulis menggunakan tiga tahapan mulai dari level realitas, representasi dan ideologi. Berikut adalah beberapa aspek yang akan digunakan peneliti berdasar ketiga level semiotika John Fiske. Pada level realitas peneliti menggunakan beberapa aspek semiotika yakni penampilan (appearance), pakaian (dress), cara berbicara (speech), gerakan (gesture) / perilaku, ekspresi (expression). (Fiske, John. 1987). Sedangkan pada level representasi peneliti menggunakan aspek representasi yakni kamera (camera), pencahayaan (lighting), musik (music), suara (sound). Sedangkan pada representasi konvensional yang 
mencakup, percakapan (dialogue) dan keadaan (setting). Tahap terakhir dari analisis John Fiske adalah ideologi. Aspek Ideologi yang digunakan oleh peneliti adalah ideologi individualisme (Fiske, 1987).

\section{HASIL DAN PEMBAHASAN}

Berdasarkan observasi pada film Kill The Messenger terdapat 16 scenes dari 164 keseluruhan scene yang memiliki kaitan dengan profesionalitas wartawan. Pada level realitas, representasi profesionalitas wartawan terlihat pada aspek penampilan dan pakaian, cara berbicara, perilaku atau gerakan, dan ekspresi dalam film Kill the Messenger.

Pada aspek penampilan dan pakaian, film Kill the Messenger memperlihatkan penampilan dan cara berpakaian Gary Webb dalam dunia nyata, yakni menggunakan lapisan dalam kaos atau kemeja, ditambah outer blazer serta celana jeans. Terkadang Gary hanya menggunakan kemeja tanpa blazer. Cara berpakaian penampilan ini disesuaikan dengan keadaan di mana dia sedang bertugas. Seperti pada scene 15, 16 dan 53, Gary menggunakan kaos dilapisi blazer, menunjukkan kesan casual. Serta pada scene 42 Gary menggunakan kemeja dengan kacamata hitam yang memberikan kesan 'menutupi identitas' saat melakukan observasi pada lokasi pengedaran Ricky Ross. Gary menyesuaikan cara berpakaian dan penampilan untuk melancarkan aksinya dalam menggali informasi berkaitan dengan kasus yang sedang diteliti olehnya. Sebagai seorang wartawan dia juga berpenampilan rapi, menyesuaikan dengan orangorang yang akan ditemuinya untuk mendapatkan informasi.

Pada aspek cara berbicara, film Kill the Messenger memperlihatkan bagaimana Gary Webb menggunakan cara berbicara yang berbeda berdasarkan situasi yang dialaminya sebagai seorang wartawan profesional.. Pada scene 16 saat Gary berjumpa dengan Coral untuk membahas informasi, Gary menggunakan cara berbicara santai karena Coral adalah warga sipil yang tidak memiliki kaitan apa-apa dengannya. Coral hanya datang meminta bantuan kepada Gary untuk menelusuri kasus ini, sehingga Gary menyambutnya dengan ramah. Cara berbicara Gary berbeda dengan scene 22, 35, dan 53 saat dia sedang menggali informasi. Cara berbicaranya cenderung to the point dan tidak banyak mengeluarkan kata-kata. Dia tidak banyak mengeluarkan kata-kata agar semakin banyak informasi yang dikeluarkan oleh lawan bicaranya. Biasanya cara yang digunakan Gary adalah dengan mengungkapkan fakta sesungguhnya (jika lawan bicaranya menutup informasi). Cara berbicara terlihat berbeda pada scene 148, saat diadakannya rapat untuk menghentikan aksi Gary bersama dengan agen. Nada bicara Gary menjadi lebih keras dan tegas, serta beberapa kali melontarkan kata-kata kasar. Hal ini dikarenakan Gary sadar rapat ini hanya sebuah kerjasama yang menguntungkan beberapa pihak, serta melanggar peran wartawan yang sebenarnya yaitu menyodorkan informasi factual kepada publik.

Pada aspek gerakan atau perilaku Gary lebih sering menggunakan gerakan yang menimbulkan kesan perilaku hangat seperti membuka mata lebar-lebar, menatap wajah secara langsung, bergerak mendekat dan menganggukkan kepala seperti yang ditemui pada scene 15, 35, 38, 43, 98, 105, dan 143.

Perilaku hangat ini dilakukan oleh Gary Webb untuk mendapatkan informasi dari narasumbernya. Menatap mata memberikan sebuah kesan kepercayaan karena narasumber Gary adalah orang-orang penting. Tatapan mata ini juga membuat lawan bicaranya berbicara 
lebih jujur, karena dengan tatapan mata secara langsung dapat terlihat apakah lawan bicaranya sedang berbohong atau jujur. Gary juga akan mendekati lawan bicaranya untuk mendapatkan informasi lebih detail, serta beberapa gerakan hangat mengangguk yang digunakan pada kondisi tertentu untuk menginformasikan sebuah pesan pada lawan bicaranya. Selain perilaku hangat pada film ini Gary juga menunjukkan perilaku dingin, yang terlihat pada scene 22, 62, dan 148. Perilaku dingin ditunjukkan Gary dalam scene 22. Gary menunjukkan perilaku dingin untuk menyudutkan lawan bicaranya yakni Russel yang tampak menyembunyikan sebuah rahasia besar.

Hal ini berbeda dengan scene 62, Gary berjalan menjauhi Fred guna memberikan jeda pada pembicaraanya, karena Fred mengucapkan kalimat yang tidak masuk akal bagi Gary. Dia melakukan itu agar Fred mengucapkan fakta sesungguhnya. Pada scene 148, Gary berperilaku dingin karena ada perlawanan dari orang-orang di sekitarnya yang menginginkan kasus ini diselesaikan dengan cara memberikan surat terbuka yang menyatakan bahwa ada kesalahan dari berita yang dibuat Gary.

Pada aspek ekspresi, dalam film Kill the Messenger bentuk profesional wartawan terlihat dari beberapa ekspresi yang terdapat pada scene 22, 35, 38, 74 dan 148. Sebagai seorang wartawan profesional Gary dituntut untuk mendapatkan informasi yang berdasar fakta. Namun kasus yang sedang dijalankan oleh Gary merupakan kasus besar dan melibatkan orang besar juga. Gary membutuhkan cara bagaimana untuk mendapatkan informasi benar dari orangorang asing tersebut, seperti pada scene 22 saat berbicara dengan Russel. Sebagai kuasa hukum Danilo Blandon, Russel tidak mungkin memberikan informasi penting kepada Gary, karena nama Gary sudah dikenal karena berita yang dibuatnya. Gary mencoba memberitahu apa yang dimilikinya sebagai sebuah peringatan kepada Russel. Terlihat ekpresi takut dari raut wajah Russel, walaupun Russel tetap tidak ingin membuka rahasia yang dimilikinya.

Pada scene 35 dan 38 terlihat bagaimana Gary memainkan emosi seseorang untuk mendapatkan informasi penting. Scene 35 saat Gary bertemu dengan Alan. Awalnya Alan tidak ingin memberitahu Gary apa yang sebenarnya terjadi, namun sebagai wartawan profesional Gary dapat mengatur dirinya untuk bertindak guna membantu proses pencarian informasi. Gary membuka informasi yang didapatkannya yakni Grand Jury Transcript di mana di dalam data tersebut tertulis Danilo Blandon akan melawannya di dalam persidangan. Alan pun marah dengan perilaku egois Danilo Blandon. Hal ini yang membuat Alan akhirnya menjadi percaya pada Gary, bahkan membantunya bertemu dengan kliennya, Ricky Ross. Cara serupa digunakan oleh Gary untuk mendapatkan informasi dari Ricky yang membuka semua informasi yang dia miliki tentang Danilo Blandon, serta tempat di mana 'barang' tersebut diedarkan oleh Ricky.

Ekspresi lainnya terlihat pada scene 74 saat Gary diajak DC untuk bertemu dan membicarakan tentang kasus yang sedang dikerjakan. Pada scene ini ekspresi Gary terlihat kaget, karena DC mengajak kerjasama dengan dirinya, namun Gary tidak mudah disuap atau menjaga independensinya. Gary hanya terlihat terkejut dan memutuskan untuk segera mempublikasikan hasil tulisannya sebelum DC bertindak lebih jauh. Serta pada scene 148 ekspresi yang dikeluarkan Gary adalah ekspresi marah, ketika mengetahui rekan kerjannya berbalik arah melawan dirinya. Padahal apa yang dilakukan rekan kerjanya melanggar etika jurnalis (mereka memberitakan berita palsu). 
Pada level representasi, representasi profesionalitas wartawan terlihat pada aspek kamera (camera), pencahayaan (lighting), musik (music), suara (sound). Sedangkan pada representasi konvensional yang mencakup, percakapan (dialogue) dan keadaan (setting).

Pada aspek kamera, representasi profesionalitas wartawan dalam film Kill the Messenger ditunjukkan dengan teknik kamera medium close shot, two shot, over shoulder shot, close up, group shot dan long shot. Beberapa teknik kamera yang digunakan pada film Kill the Messenger memberikan makna profesionalitas wartawan terdapat pada scene 31 dan 34, 38, 42, 62, 74, dan 98.

Pada scene 31 dan 34, teknik kamera yag digunakan adalah medium close dan close up. Pesan yang ingin disampaikan pada scene ini adalah bahwa Gary serius dalam kasus ini. Dia mencari fakta terlebih dahulu mengenai orang yang pernah terlibat didalam kasus pengedaran ini, terutama pelaku yang memiliki peranan cukup besar.

Pada scene 38, teknik kamera yang digunakan adalah Group shot di mana pesan yang ingin disampaikan adalah bahwa Gary dapat mengambil sebuah keputusan menggunakan hak khusus sebagai seorang wartawan. Scene ini memperlihatkan Gary berbicara dengan Ricky Ross dialam ruang pertemuan penjara. Kesan yang ditunjukkan pada scene ini adalah sebuah 'rahasia' serta ada tulisan "hands in plain view" yang berarti "tangan terlihat jelas".

Teknik kamera lainnya yang menangkap tingkah profesional Gary dalam mengambil keputusan adalah pada scene 42. Teknik yang digunakan adalah long shot, menangkap gerakan Gary dari jarak jauh. Dia digambarkan sedang berjalan di sekitar pemukiman tempat Ricky mengedarkan obat-obatan. Teknik ini memberikan makna bahwa Gary dapat mengontrol dirinya dalam bertindak. Hal ini dikarenakan lokasi tersebut bukanlah lokasi yang tepat untuk menggali informasi seputar obat-obatan, apalagi Gary seorang wartawan.

Pada scene 62 teknik yang digunakan adalah two shot, long shot, over the shoulder shot. Makna yang dihasilkan dari scene ini adalah bagaimana cara Gary menggali informasi dan mengontrol dirinya. Di sisi lain scene ini menggambarkan sebuah kerahasiaan informasi yang dimiliki oleh Gary karena scene ini berlatarkan gedung putih. Pada scene 74 teknik kamera yang digunakan adalah medium close dalam adegan ini kamera menunjukkan posisi Gary yang terpojokkan oleh beberapa orang yang menjadi bagian DC. Namun meskipun kondisi saat itu Gary terpojok, dia berhasil untuk menolak ajakan dari DC dan langsung menulis laporan mengenai kasus ini. Apa yang dilakukan Gary menunjukkan kaitan dengan independensi seorang wartawan. Pada scene 98 teknik kamera yang digunakan adalah two shot dan close up. Pada adegan ini adalah dimana kamera menunjukkan wajah Gary yang terlihat serius dalam membenarkan berita yang 'dipelintir' oleh media. Sebagai seorang wartawan, tindakan Gary adalah tindakan yang tepat karena sebagai seorang wartawan sudah wajib untuk mengabarkan berita yang benar kepada publik.

Pada aspek pencahayaan, representasi profesionalitas wartawan dalam film Kill the Messenger ditunjukkan dengan teknik back light. Teknik ini terdapat pada scene 98. Walaupun posisi sesungguhnya posisi lampu berada di depan, namun sajian visual yang menampilkan frame ini menjadikan lampu tersebut sebagai cahaya belakang atau back light. Cahaya belakang ini untuk memperjelas bayangan objek yakni Gary dan Presenter. Makna yang ditimbulkan dari pencahayaaan ini adalah menambah kesan keseriusan Gary dalam menjelaskan mengenai kebenaran informasi yang sesungguhnya. Hal ini didukung dengan pencahayaan karena sebagian wajah tertutup oleh bayangan sehingga membangun suasana gelap. 
Pada aspek musik, semua adegan yang memiliki musik dalam film Kill the Messenger menggunakan musik instrumental. Scene yang menggunakan musik pada film Kill the Messenger terdapat pada scene 15, 31 dan 34, 35, 98, dan 150. Ada scene yang memiliki kaitan dengan profesionalitas wartawan, terletak pada scene 31 dan 34 di mana musik yang digunakan adalah musik menegangkan, yang memberikan sebuah makna 'semangat' Gary dalam membuat berita untuk memberitakan sebuah fakta yang harus diketahui publik. Scene lain yang berkaitan dengan profesionalitas wartawan terdapat pada scene 150. Musik dalam adegan ini menggambarkan suasana perasaan Gary yang kacau. Ketika Gary ingin menandatangani lembar pengunduran dirinya, musik ditambahkan beberapa suara dentuman. Makna dari musik ini menggambarkan kebimbangan Gary saat mengambil keputusan terakhirnya namun Gary tetap memutuskan keputusannya untuk menandatangani surat pengunduran dirinya.

Pada aspek efek suara terdapat pada scene 150. Pada scene ini terdengar suara televisi yang menyiarkan berita tentang Gary menarik kembali berita yang dibuatnya karena adanya penyederhanaan informasi. Kata-kata di dalam efek suara sebagai berikut.

Beberapa jurnalis berpengalaman di Amerika telah memeriksa hasil kerja Webb, dan menemukan keteledoran, dan sering salah. Minggu ini, Webb telah menarik cerita tentang $\mathrm{CIA}$, setelah editornya mengakui bahwa tulisan tersebut disederhanakan mengenai pengedaran narkoba. Dia juga menulis " Aku merasa bahwa kita tak memiliki bukti bahwa pejabat tinggi CIA tahu" banyak orang Amerika tampaknya bersedia percaya bahwa pemerintah mereka sendiri bisa terlibat dalam penyeludupan narkoba. Meskipun ada kritik terhadap hasil kerja Webb dia dijadwalkan untuk menerima Bay Area Journalist of the Year Award. Beberapa organisasi memperdebatkan apakah dia layak untuk ini.

Efek suara ini memiliki makna bahwa Gary harus segera keluar dari lingkaran ini, serta menambah tekanan emosi Gary saat menandatangani surat pengunduran dirinya. Beberapa hal yang mendukung Gary memutuskan untuk keluar adalah disiarkannya konten di televisi yang disebut mengklarifikasi bahwa berita yang dibuat Gary itu salah. Konten ini ditayangkan tanpa adanya izin dari Gary karena dia sangat yakin atas kebenaran berita tersebut.

Pada aspek percakapan pada film Kill the Messenger terdapat pada scene 15, 16, 22, 35, $38,42,43,53,62,74,98,105,143$, dan 148 . Scene yang memiliki kaitan dengan profesionalitas wartawan terdapat pada scene 16, dialog di dalam adegan ini menunjukkan bahwa Gary mengatur dirinya dengan sangat hati-hati karena kasus ini adalah kasus besar dan sensitif. Gary tidak mudah untuk dihasut maupun dirayu oleh Coral, meski gaya berpakaiannya mencolok dan minim, serta gerakan hangat yang lebih banyak ditunjukan oleh Coral. Coral bercerita panjang mengenai Danilo Blandon, di akhir kalimat Coral mengucapkan sebuah kalimat "Mengapa menggunakan ikan paus untuk menangkap ikan patin? Itu masuk akal bagimu Gary Webb?" kalimat ini seolah-oleh mengajak Gary untuk sepemikiran dengan Coral. Sebagai seorang wartawan profesional Gary tidak mudah dihasut. Gary pun mengontrol dirinya dengan berkata "Tidak terlalu masuk akal. Tak masuk akal. Kau punya lebih banyak dokumen?".

Dialog ini menyampaikan sebuah pesan bahwa, Gary mengatur dirinya dan mengucapkan kalimat yang tepat. Gary tidak langsung menyetujui pola pikir yang dibangun oleh Coral. Dia juga tidak tertarik dengan kasus persidangan Raffie, dia lebih tertarik dengan kasus lingkaran narkoba yang memiliki kaitan dengan pemerintah. Makna yang dihasilkan dari dialog ini adalah Gary mengontrol dirinya untuk tidak terburu-buru dalam mengambil 
keputusan mengenai kasus ini, karena apa yang dilihat Gary bukan sebatas kasus Raffie, masih ada peran besar dibalik kasus ini.

Pada scene 35, Gary langsung bertanya apakah Alan mengenal Danilo Blandon. Jawaban Alan bernuansa abu-abu yakni "mungkin." Jawaban tersebut sama sekali tidak menjawab pertanyaan Gary. Gary lantas mencoba memancing informasi lebih lanjut dengan berkata "Karena kupikir dia akan bersaksi melawan klienmu besok." Melalui kalimat ini emosi Alan terpancing. Dia pun mengatakan "Tidak, kau salah informasi. Blandon dan klienku adalah teman sekaligus rekan. Jika dia akan bersaksi, dia akan bersaksi membela Ricky." Dari pertanyaan pertama Gary mendapatkan informasi bahwa Danilo Blandon dan Ricky memiliki hubungan yang cukup dekat. Bahkan Alan sendiri menganggap mereka adalah rekan yang saling membela satu dengan yang lain. Setelah mendapatkan informasi kedekatan Danilo dan Ricky, Gary tetap berusaha menggali informasi lebih dalam.

Informasi selanjutnya yang didapatkan oleh Gary adalah bahwa Alan sudah pernah bertanya mengenai hal ini, bahkan Russel selalu menjawab siapa orang yang ada di balik namanya. Namun tidak untuk Danilo Blandon. Russel pandai menutupi informasi penting. Jika Alan bertanya mengenai sesuatu yang besifat sensitif Russel selalu menjawab dengan alasan keamanan nasional. Mendengar kata "keamanan nasional" menimbulkan kejanggalan pada kasus ini. lantas Gary kembali bertanya "Keamanan nasional dan pengedar kokain dalam kalimat yang sama? Apakah itu tak terdengar aneh bagimu?" kesimpulan yang diambil Gary membuat Alan curiga, Alan pun bertanya “Oke, apa sebenarnya yang kau inginkan?" Gary kembali membuka peluang untuk mendapatkan informasi lebih banyak mengenai kasus ini. Percakapan ini menimbulkan sebuah makna bahwa dari awal kedatangan Gary untuk mendapatkan informasi lebih lanjut mengenai Danilo Blandon. Berhubung di awal Alan masih menutupi informasi menenai Danilo, maka Gary membuka rahasia mengenai Danilo sehingga Alan berpihak pada dirinya, apa yang dilakukan Gary untuk mendapatkan informasi lebih lanjut mengenai Danilo dan kasus ini.

Scene 38, Gary membuka pertanyaan pertama dengan menanyakan Danilo kepada Ricky, namun Ricky menyangkal pertanyaan Gary. Hal ini terjadi karena Gary dan Ricky belum saling kenal serta adanya perbedaan ras dan kelas. Gary merupakan seorang wartawan, sedangkan Ricky adalah terduga pengedar narkoba, sangat riskan untuk menjawab pertanyaan tersebut. Untungnya Alan terlihat melakukan gerakan bersifat hangat, dia mengangguk keara Gary, seolah mengijinkan Gary untuk mengatakan yang sesungguhnya.

Gary pun menjelaskan permainan Danilo terhadap dirinya. Mendengar pernyataan ini membuat emosi Ricky naik. Sisi positif dari kemarahan Ricky adalah terciptanya kepercayaan terhadap Gary. Ricky pun memberikan beberapa fakta mengenai Danilo Blandon. Makna yang dihasilkan dari dialog ini adalah Gary hanya meberikan beberapa pertanyaan pancingan agar Ricky menceritakan semua mengenai Danilo serta pengalaman yang terjadi selama berbisnis bersama Danilo. Semua kembali lagi kepada tujuan untuk menggali informasi.

Scene 42, saat mengetahui semua ini, Gary terpanggil untuk segera menemui Blandon, membongkar semua jaringan yang bersembunyi dibalik dirinya, guna memberikan informasi kepada masyarakat berdasarkan fakta yang akurat. Makna yang timbul di sini adalah Gary berupaya membongkar semua rahasia, salah satunya dengan mendapatkan informasi langsung dari Danilo Blandon, sehingga informasi dapat segera dipublikasikan. 
Gary memang seorang wartawan yang memiliki kewajiban untuk menggali informasi. Namun pada kondisi ini sepertinya Gary harus mengatur dirinya dengan cara memberikan kesempatan bagi Alan untuk mengungkapkan kebenaran pada persidangan, karena Alan memiliki kuasa untuk memberikan Danilo Blandon pertanyaan, makna yang timbul dari dialog ini adalah Gary sadar dia tidak memiliki kekuatan untuk menggali informasi yang diketahui oleh Danilo secara langsung. Namun Gary menunrunkan egonya dengan cara mengambil keputusan lain, yakni menggunakan kekuatan Alan saat dipersidangan nanti.

Scene 43, Alan bingung dan bertanya kepada Gary, apa yang harus ditanyakan kepada Danilo Blandon. Hal ini dikarenakan pertanyaan yang ditulis oleh Gary hanya inti dari pertanyaan. Hal ini terjadi karena kebiasaan Gary sebagai seorang wartawan (menggunakan tulisan singkat saat menangkap informasi ketika wawancara). Gary juga menjelaskan kepada Alan bahwa tanyakan kepada Danilo apakah dia memiliki rekan atau lembaga pemerintah yang bekerjasama. Makna yang dihasilkan dari dialog ini adalah Gary ingin mendapatkan informasi mengenai siapa sosok dibalik Danilo Blandon yang mengatur semua pengedaran ini. Dasar dari pertanyaan ini adalah ketika ada hubungannya pengedaran ini dengan keamanan nasional, seperti yang dikatakan Alan saat berada dikantornya kala itu.

Scene 53, Berikut adalah beberapa dialog penting yang berisi informasi yang dikatakan oleh Norwin Meneses.

\footnotetext{
“Tapi kau perlu melihat dari sudut pandang kami. Jika pergerakan Contra tak diampingi teman dan uang, kami akan terpaksa hidup dibawah pemerintah yang diktator menyuruhmu ini itu, mengatur pola pikir."

"Mereka selalu mencari cara untuk mengumpulkan uang untuk perang ini. Ada suatu masa ketika Ollie, Ollie pergi ke teman-temannya di Washington, dan itu setahun yang lalu."

"Dia berkata, kenapa kita tidak menggunakan uang hasil sitaan kokain untuk mendanai dan mendukung perang Contra? Tentu saja mereka menolak, tapi seperti yang kau lihat, Ollie bukan satu-satunya orang yang punya ide tersebut. Ujung-ujungnya menghalalkan segala cara."

"Kalian orang Amerika tak ingin kelapa atau pisang. Kalian ingin kokain, dan aku tahu dimana mendapatkan kokain."
}

Informasi pertama adalah peredaran narkoba ini bertujuan untuk mendanai perang Contra, di mana negara Norwin membutuhkan uang dan senjata. Sedangkan sangat sulit negara kecil seperti Nicaragua untuk melakukan bisnis yang menghasilkan, salah satu yang mereka punya adalah kokain. Maka dari itu mereka memanfaatkan komoditas tersebut untuk bertransaksi demi mendapatkan uang dan senjata.

Informasi ke dua adalah awal mula ide ini berasal dari Oliver North, dimana dia menyarankan untuk menggunakan uang hasil sitaan kokain untuk mendanai perang dingin tersebut, berawal dari ide tersebut membuat mereka melakukan transaksi ini untuk mendapatkan uang dan senjata.

Informasi ke tiga adalah ketika Norwin secara tidak langsung mengakui bahwa dia adalah sumber dari narkoba tersebut. Berdasarkan kalimat yang diucapkannya. "Kalian orang Amerika tak ingin kelapa atau pisang. Kalian ingin kokain, dan aku tahu dimana mendapatkan kokain."

Makna yang dihasilkan dari dialog diatas adalah sebuah informasi penting yang berhasil didapatkan Gary berupa fakta dan alasan di balik semua lingkaran pengerdaran narkoba. 
Selain informasi yang didapatkan Gary terdapat juga makna lain di balik dialog ini yakni Gary menghadapi sebuah keputusan. Norwin Menses sudah memberikan kebenaran yang sesungguhnya kepada Gary. Namun pada akhir dialog Norwin dia berkata, "Sekarang karena kau sudah tahu yang sebenarnya, kau akan dihadapkan dengan keputusan paling penting dalam hidupmu." Makna dari dialog ini sebenarnya adalah bahwa Norwin sudah tahu risiko yang akan terjadi jika Gary memutuskan untuk bertahan menelusuri kasus ini, yang akan terjadi adalah sebuah kehancuran bagi diri Gary, Norwin juga bertanya "Kau punya keluarga? Kau sudah menikah? " karena kasus ini juga akan berdampak kepada keluarganya, maka dari itu Norwin menyarankan Gary untuk bertemu dengan orang bernama Fred Weil. Namun Gary tetap profesional, dia tetap menjalankan kasus ini. Walaupun akan mengancam dirinya.

Scene 74, apa yang dikatakan oleh DC membuat Gary terkejut. Gary mengira kedatangan dirinya akan mendapatkan percakapan penting mengenai informasi yang didapatkan oleh dirinya. Namun kenyataannya DC memiliki strategi buruk, yakni ingin menghancurkan masyarakat AS terutama kaum muda. Seperti perkataan DC, "Anak-anak Amerika akan mati dalam perang itu." Gary menjawab bahwa, "Anak-anak Amerika masih sekarat."

Apa yang dikatakan oleh DC membuat Gary terkejut. Gary mengira kedatangan dirinya akan mendapatkan percakapan penting mengenai informasi yang didapatkan oleh dirinya. Namun kenyataannya DC memiliki strategi buruk, yakni ingin menghancurkan masyarakat AS terutama kaum muda. Seperti perkataan DC "Anak-anak Amerika akan mati dalam perang itu." Gary menjawab bahwa "Anak-anak Amerika masih sekarat." Dia berjuang melalui berita ini bahwa warga Amerika masih memiliki kesempatan untuk menyelamatkan anak-anaknya dengan menyampaikan informasi ini. Hasrat melayani masyarakat Gary terpancing ketika DC mengucapkan, "Kami tak pernah mengancam anak-anakmu Webb." Mendengar kalimat tersebut tak membuatnya kehilangan niat, dia justru segera pergi dan menulis beritanya. Ini dilakukan Gary karena dia tidak pandang bulu, bukan karena mereka tidak mengancam anak Gary menjadi alasan Gary tidak menerbitkan berita ini. Dialog satu ini menghasilkan makna yang berkaitan dengan sifat independen Gary, apa yang dikatakan oleh The Agency karena tidak menyerang anaknya bukan jaminan negosiasi yang ingin diterima Gary.

Scene 98, ketika Gary mendengar bahwa hasil laporannya mengalami pemelintiran fakta dia langsung bergegas pergi ke stasiun televisi. Dalam dialognya, dia menjelaskan mengenai apa yang terjadi sesungguhnya. "Banyak orang mengatakan, tentu saja, termasuk orang-orang di kongres bahwa CIA sengaja menyuruh orang-orang Afrika-Amerika mengedarkan kokain," ucap presenter. Gary langsung mengatakan bahwa media tersebut telah memelintir kata-kata yang ditulisnya. Selanjutnya Gary menjelaskan inti dari tulisannya "Apa yang CIA inginkan adalah perang yang mana tidak diinginkan oleh kongres. Dan reaksi untuk hal tersebut, apa yang terjadi di Los Angeles selatan dan kota-kota Amerika lainnya adalah sebuah kesalahan." Dialog tersebut bermakna bahwa Gary bertanggung jawab terhadap hasil tulisannya dengan tujuan untuk meluruskan fakta yang telah dipelintir oleh media.

Scene 105, dalam dialog ini Gary sudah mendapatkan gambaran mengenai apa yang akan terjadi selanjutnya jika dia tetap menjalankan niatnya untuk membongkar kasus ini. Fred mengatakan, "Mereka akan membuat cerita buruk tentangmu. Kau memiliki riwayat skizofrenia, kau pembohong, kau homo, kau memukuli anjingmu, kau pedofil, tak masalah jika itu tak benar. Intinya adalah tak ada yang ingat apa yang kau temukan, mereka mengingatmu 
sebagai orang gila." Semua risiko tersebut juga sudah didengar oleh Gary namun tidak ada niat untuk berhenti dari kasus ini. Gary tetap berada pada keputusannya untuk berjuang agar berita ini dapat diterbitkan. Makna yang timbul dari dialog ini adalah Gary tetap mengambil sebuah keputusan untuk melanjutkan kasus ini. Fred juga menjadi orang yang mendukung apa yang sudah dikerjakan oleh Gary, karena menurut Fred, apa yang sudah dilakukan Gary sejauh ini merupakan perjalanan terjauh sepanjang kasus ini dikerjakan oleh berbagai orang.

Scene 143, Kedatangan Cullen secara misterius memang sedikit aneh, namun dari pembicaraan antara Gary dan Cullen menimbulkan makna bahwa masih ada rasa untuk melayani masyarakat apalagi ditambah kedatangan Cullen ke motelnya. Hal ini terbukti ketika Cullen berkata "Apa semua ini sama? Y a mereka sama. Danilo Blandon. Ini dia kemarin, kau disini, saat ini. Tak seorangpun ingin mendengar kisah sedihmu, Gary." Sambil menunjukkan foto Danilo Blandon bersama seorang wanita. Tekad Gary dalam memberitakan kasus ini sudah bulat. Bisa saja Gary memberhentikan perjuangannya dalam kasus ini. Cullen sudah mengatakan bahwa tidak ada yang mau mendengar kisah sedihnya Gary. Arti lain dari perkataan ini adalah perjuangan Gary sebenarnya sia-sia. Blandon yang harusnya berada dibalik sel, dapat berkeliaran menikmati hidupnya. Sedangkan Gary yang mati-matian berjuang agar kebenaran terungkap justru diasingkan ke media lokal, tinggal di motel sederhana dan hidup menderita. Namun Gary tetap berusaha melanjutkan perjuangannya agar masyarakat tetap menerima informasi yang benar.

Scene 148, ketika Gary mendengar bahwa semua yang dilakukannya sia-sia, seperti apa yang sudah dikatakan oleh Fred Weil dalam panggilan telepon. CIA bermain sangat rapi sehingga dapat menghilangkan semua bukti perjuangan Gary dalam menggali fakta di lapangan.

Bukti sikap independen Gary adalah saat menolak solusi dari Jerry yang mengatakan "Kita akan mencetak surat terbuka mengatakan bahwa terjadi beberapa kesalahan." Gary dengan tegas mengatakan "Jangan lalukan itu!" dengan ekspresi marah diraut wajahnya. Amarahnya semakin meningkat saat " $X$ " (sosok asing yang berada didalam rapat) mengatakan "Ayolah, sudah ada gambaran besar, buka matamu." Gary langsung menjawab, "Mataku terbuka lebar. Tahu apa yang kulihat? Aku melihat sekelompok orang yang khawatir tentang reputasi mereka. Ketakutan bahwa majalah Post atau Times takkan memakai jasa kalian atau memberi pekerjaan pada kalian. Kau tahu Jerry, jika kau mencetak surat itu, kau tak bisa membatalkannya, takkan pernah. Kau bisa menceritakan kebenaran hanya karena kau merasa seperti itu."

Perkataan ini juga dikuti dengan gerakan dingin, yakni Gary pergi menjauh, menunjukkan sikap acuh tak acuh karena situasi ruangan sudah tidak netral. Dialog ini dapat dimaknai bahwa Gary menunjukkan sikap independennya sehingga dia tidak mau memberikan berita palsu hanya untuk mempertahankan reputasi. Semua orang berhak mendapatkan informasi yang benar, bukan karena sifat egois demi sebuah reputasi.

Pada aspek setting, pada film Kill the Messenger setting terdapat pada scene 35 dan 38. Scene yang merepresentasikan profesionalitas wartawan terdapat pada scene 38 yakni Setting tempat saat itu hanya terdapat meja dan kursi, sisanya hanya tembok putih. Ada tulisan "hands in plain view" yang berarti tangan terlihat jelas. Setting tempat ini bermaknakan sebuah ruangan tertutup, terlihat ini seperti ruangan pertemuan para narapidana dengan tujuan khusus. Pintu masuk dijaga dengan ketat. Tulisan di tembok tersebut mengartikan bahwa meskipun ruangan ini tertutup, apapun yang dilakukan tetap diawasi, tidak ada rahasia, apapun 
transaksi yang dilakukan melalui tangan anda juga terlihat jelas. Sehingga peran profesional Gary dalam menggali informasi terlihat di sini dan bagaimana Gary mengontrol dirinya saat berhadapan Ricky Ross.

Pada level ideologi, film Kill the Messenger didominasi dengan ideologi individualisme. Representasi profesionalitas wartawan terlihat melalui ideologi individualisme terlihat pada scene 16, 31 dan 34, 43, 98, 148, dan 150.

Scene 16, Gary melakukan keputusan cepat untuk bertemu dengan Coral, dengan tujuan segera mendapatkan informasi lebih lanjut mengenai kasus ini terutama transkrip yang dimiliki oleh Coral. Apa yang dilakukan Gary mengarah ke ideologi individualisme vertikal. Individualisme vertikal lebih bersifat independen dan otonom, kompetitif dan berusaha menjadi yang terbaik dan berusaha untuk mendapatkan posisi status yang tinggi. Makna yang timbul dari ideologi tersebut adalah bahwa apa yang dilakukan Gary tertuju pada dirinya (individual) untuk mendapatkan berita bagus dan berbobot, serta layak diketahui masyarakat.

Scene 31 dan 34, Gary terlihat sedang mencari informasi mengenai tersangka kasus ini, setelah kejadian kasus Raffie dimana pada kenyataannya Coral ternyata menggunakan Gary untuk menakuti Russel, sehingga kasus Raffie dibatalkan. Kejadian ini membuat Gary terpaksa mencari cara untuk mendapatkan informasi tanpa Coral, karena dia sudah memiliki data transkrip. Apa yang dilakukan Gary menunjukkan ideologi individual vertikal. Individualisme vertikal lebih bersifat independen dan otonom, kompetitif dan berusaha menjadi yang terbaik dan berusaha untuk mendapatkan posisi status yang tinggi. Apa yang dilakukan Gary dengan cara mencari informasi secara mandiri menunjukkan ada sesuatu yang ingin dia raih dengan tindakan yang dilakukan oleh dirinya, yakni mencari data secara mandiri, agar informasi yang dia dapatkan saat ini dapat segera dipublikasikan kepada masyarakat.

Scene 43, pada kondisi ini Gary sedang memperjuangkan apa yang ingin didapatkannya di dalam persidangan ini, yakni informasi lebih lanjut dari Danilo Blandon. Sedangkan Alan juga membutuhkan bantuan Gary dalam membongkar kasus ini. Mereka berdua memiliki kepentingan masing-masing. Namun mereka tidak mendominasi satu dengan yang lainnya. Adengan ini tertuju pada individualisme horizontal. Individualisme horizontal menganggap dirinya sangat otonom dan percaya bahwa kesetaraan antarindividu merupakan hal yang ideal. Mereka tidak tertarik untuk memiliki status yang lebih tinggi dari anggota kelompok lainnya. Makna yang dihasilkan dari ideologi ini adalah tujuan Gary sebenarnya hanya untuk mendapatkan informasi mengenai Danilo melalui Alan. Hal sebaliknya juga terjadi pada Alan. Dia memerlukan Gary untuk membantu Ricky agar terbebas dari kasus ini.

Scene 98, Gary melakukan ini karena adanya pemelintiran informasi pada adegan sebelumnya, Gary langsung bergegas pergi ke acara dan melakukan konfirmasi mengenai kebenaran informasi yang sesungguhnya. Apa yang dilakukan Gary adalah untuk membenarkan fakta, namun dibalik kejadian tersebut ada ideologi yang terkait pada individualisme dalam diri Gary. Jika informasi yang dikatakan Gary mengarah ke informasi yang palsu, jelas akan merusak nama baiknya serta media yang dibawanya. Demi mencapai sebuah pencapaian besar dan jiwa profesionalnya, Gary melakukan hal ini. Tindakan yang dilakukan Gary mengacu pada ideologi Individualisme vertikal. Makna yang dihasilkan dari ideologi adalah bahwa yang dilakukan Gary memang demi reputasinya dan kantornya. Di sisi lain Gary juga ingin menyampaikan fakta sesungguhnya kepada masyarakat, agar tidak terjadi kesalapahaman informasi mengenai kasus ini. 
Scene 148 menunjukkan sikap Gary yang berusaha untuk mendominasi orang-orang di sekitarnya. Dalam hal ini Gary melakukan hal yang betul. Mendominasi yang dimaksud adalah Gary ingin menegakkan kebenaran yang terjadi. Hal ini dikarenakan di dalam ruangan tersebut tidak ada orang yang berdiri sebagai kubu Gary Webb, semuanya tertarik dengan negosiasi demi mempertahankan reputasi untuk keuntungan semata. Makna yang ditunjukkan pada adegan ini adalah bahwa Gary tidak mementingkan reputasi. Dia menolak semua tawaran yang diberikan dengan menunjukkan sikap dingin, serta melawan menggunakan kata-kata kasar, karena mereka terlihat bekerjasama untuk menjatuhkan Gary saat itu.

Scene 150, Gary mengambil keputusan berdasar pada dirinya sendiri dan demi kepentingan dirinya sendiri. Apa yang diperjuangkan Gary untuk mencapai sebuah pencapaian besar dialihkan melalui jalan lain. Gary tidak membutuhkan Mercury news untuk mewujudkan keinginannya membongkar semua kasus ini. karena memang mereka sudah berpihak kepada pemerintah demi sebuah reputasi. Gary memutuskan untuk berjalan sendiri untuk membuka kasus ini. Ideologi berdasarkan adegan ini adalah individualisme vertikal. Makna yang dihasilkan dari adegan ini adalah bahwa Gary mengambil sebuah keputusan, hal ini dikarenakan tidak adanya dukungan dari kantornya untuk kembali membuat berita benar. Sehingga jika Gary tetap berada disana, dia akan berjalan dengan kontrol pemerintah.

\section{KESIMPULAN}

Berdasarkan hasil analisis dapat disimpulkan bahwa wartawan dalam film Kill The Messenger sudah merepresentasikan profesionalitas wartawan. Bentuk representasi profesionaltas wartawan bedasarkan hasil analisis sebagai berikut:

Pertama, menghasilkan berita yang faktual dan jelas sumbernya. Representasi ini muncul pada scene 31 dan 34, terlihat dari level representasi kamera dan suara yang menunjukkan Gary mencari informasi mengenai orang yang terkait pada kasus tersebut. Pada scene 35, level realitas terlihat dari cara berbicara, gerakan hangat, ekspresi. Serta level representasi percakapan dan setting. Ketika Gary melontarkan beberapa pertanyaan mengenai kasus ini kepada Alan, didukung dengan gerakan hangat Gary serta ekspresi Alan. Scene 38, pada level realitas gerakan hangat, ekspresi, serta pada level representasi percakapan. Gary berusaha mendapatkan informasi dari Ricky sebagai orang yang melakukan kegiatan peredaran narkoba. Dengan memberikan beberapa pertanyaan dan fakta sesungguhnya dibalik Danilo Blandon. Scene 43, pada level representasi percakapan. Gary menjelaskan maksud dari pertanyaannya pada Alan, untuk menggali lebih banyak informasi dari Danilo. Scene 53, pada level realitas cara berbicara, serta level representasi percakapan. Gary menanyakan informasi kepada Norwin Menesses berkaitan dengan kasus ini untuk mendapatkan informasi lebih dari sumber yang tepat dengan cara berbicara to the point.

Kedua, memiliki rasa terpanggil dan melayani masyarakat. Hal ini ditemukan pada scene 15, pada level realitas gerakan hangat. Saat Gary terdiam sejenak untuk memutuskan apakah dia harus mengambil kasus ini atau tidak saat berbicara dengan Coral melalui telepon. Scene 42, pada level representasi percakapan. Ketika Gary berkata pada Alan bahwa bagaimanapun caranya dia harus berbicara dengan Danilo Blandon, untuk mendapatkan informasi dan mempublikasikan kasus ini. Scene 62, pada level representasi percakapan. Fred mengatakan bahwa kasus ini memiliki risiko tinggi, namun Gary tetap berusaha untuk berjuang 
mempublikasikan kasus ini dengan menerima semua risiko yang sudah diucapkan Alan. Scene 74, pada level representasi percakapan. Ketika Gary melawan perkataan the Agent. Serta saat Gary langsung mengambil keputusan untuk memberitakan kasus ini di depan the Agent. Scene 143, pada level realitas gerakan hangat serta level representasi percakapan. John Cullen memberi tahu Gary apa yang dikerjakannya sia-sia. Namun Gary tetap berjuang untuk meneruskan kasus ini.

Ketiga, menghormati hak privasi. Ciri ini tidak ada di dalam adegan, namun dari beberapa adegan dimana Gary melakukan ciri "Faktual” sebenarnya disitulah titik ciri ke-3 ini. Hal ini dikarenakan Gary tidak pernah membuka identitas orang yang menjadi informan pada beritanya.

Keempat, memiliki otonomi dalam membuat keputusan, untuk kepentingan peliputan berita investigasi demi kepentingan publik terdapat pada. Scene 22, pada level realitas cara berbicara, gerakan dingin, dan ekspresi. Saat Gary memutuskan untuk mengatakan bahwa dirinya memiliki transcript persidangan. Scene 43, pada level realitas gerakan hangat. Saat Gary menghampiri Alan untuk memperjelas pertanyaan yang dia miliki. Hal ini dilakukan Gary untuk mendapatkan informasi demi kepentingan publik.

Kelima, bertanggung jawab dan transparan terhadap hasil tulisannya. Hal ini terdapat pada Scene 98, pada level realitas perilaku hangat, serta level representasi kamera, dan pencahayaan. Saat Gary melakukan klarifikasi atas pemelintiran informasi yang tersebar melalui media.

Keenam, profesional mengatur dirinya sendiri. Hal ini terdapat pada Scene 16, pada level realitas cara berbicara, serta level representasi percakapan. Ketika Gary meminta lebih banyak dokumen, untuk memastikan bahwa kasus ini memiliki data yang cukup. Scene 38, pada level realitas gerakan hangat, dan ekspresi, serta level representasi kamera. Menunjukkan bagaimana Gary bisa menyesuaikan diri dengan lingkungan ruangan tersebut dan bagaimana cara dia mendapatkan informasi di ruangan yang penuh pengawasan. Scene 42, pada level realitas penampilan serta level representasi kamera. Terlihat bagaimana Gary menyesuaikan diri dengan lingkungan pengedar narkoba dengan cara menyamar dan menutup identitas dirinya sebagai seorang wartawan. Scene 53, pada level representasi percakapan. Saat Norwin Menesses mengatakan bahwa ada risiko besar jika Gary menjalankan kasus ini dan mempublikasikan kasus ini. Scene 62, pada level realitas gerakan dingin serta level representasi kamera. Ditunjukkan bahwa Gary menahan rasa penasarannya berkaitan dengan informasi yang dimiliki oleh Fred. Hal itu dikarenakan pembicaraan mereka berada tidak jauh dari gedung putih. Scene 105, pada level realitas perilaku hangat, serta level representasi percakapan. Gary memutuskan untuk tetap berjuang pada kasus ini, meskipun Fred sudah mengatakan risiko yang akan diterima Gary. Scene 150, pada level representasi musik dan efek suara. Menggambarkan suasana hati Gary dalam mengambil keputusan untuk keluar dari media tersebut karena mereka lebih memilih menerima sogokan daripada memberitakan hal benar.

Ketujuh, bersifat independen. Hal ini terdapat pada Scene 74, pada level realitas ekspresi, serta level representasi kamera. Saat Gary marah dan memutuskan untuk memberitakan kasus ini. Scene 148, pada level realitas ekspresi, serta level representasi percakapan. Gary menolak keras adanya ajakan untuk memberhentikan kasus ini, dengan membuat berita palsu demi reputasi media San Jose Mercury News. Ideologi pada film ini 
mengarah pada ideologi individualisme yang terdapat pada Scene 16, 31 dan 34, 43, 98, 148, 150.

\section{DAFTAR PUSTAKA}

Fiske, John 1990. Introduction to Communication Studies. London \& New York: Routledge. 12. 1987. Television Culture : Popular Pleasure and Politics. London and New York: Routledge. 1,3,4. and John Hartley. 2004. Reading Television. London and New York : Routledge. 22.

Oktavianus, Handi. 2015. Penerimaan Penonton Terhadap Praktik Eksorsis Didalam Film Conjuring dalam Jurnal E-Komunikasi Program Studi Ilmu Komunikasi Universitas Kristen Petra Surabaya. 03(2), 6.

Rustam, Syahwal. 2016. "Kesejahteraan Wartawan Untuk Peningkatan Profesionalisme dan Independensi Pada AJI Makassar." (Skripsi: Fakultas Dakwah dan Komunikasi Universitas Islam Negeri (UIN) Alauddin Makassar). 16.

Sobur, Alex. 2003. Semiotika Komunikasi. Bandung: PT Remaja Rosdakarya. 11, 15.

W, Dermawan. 2003. Riset Bisnis Panduan bagi Praktisi dan Akademisi. Jakarta : PT Gramedia Pustaka Utama. 37, 119.

Wahyuningsih, Sri. 2019. Memahami Representasi Pesan-Pesan Dakwah Dalam Film Melalui Analisis Semiotik. Surabaya : Media Sahabat Cendekia. 1-2, 7-8. 